\title{
Hong Kong
}

\section{A handover of freedom?}

\section{Chris Yeung}

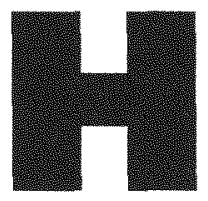

ow free is too free? Or, perhaps more accurately, how low is too low? These are the questions that officials and consumers in Hong Kong are asking as the media dishes up an increasingly sensational, voyeuristic and sometimes fictional diet of scandal, gore and intrigue. Did the Apple Daily, one of the tabloid market leaders, step over the line when it paid a labourer to pose in bed with a prostitute, thus illustrating the infidelity which drove his wife to push her two sons out of their high-rise apartment window and to jump herself? At what point does the government intervene to enforce minimum standards to protect the morals or sensibilities of society, or does the media industry itself need to rein in its own activities?

So serious is the slide into tabloid journalism in.Hong Kong that one pressure group has established a 'pollution index' to monitor the media and provide the public with a list of the most 'polluted' publications (Ming Pao, 26 April 1999). The Hong Kong Journalists Association itself warns that pressures will grow for the policing of the media if the trend in sensationalism continues, opening up new avenues for government intervention in Hong Kong, a territory jealously guarding its freedoms as the 'Special Administrative Region' (SAR) following its handover from Britain to China in 1997. Could media irresponsibility so frustrate the public that the people of Hong Kong would be willing to trade off media freedoms and bring the local press more in line with Beijing?

\section{The handover and the media}

It seems ironic that two years after the handover which came with all the fears of Communist-style controls, that the biggest concern for press 
freedom in Hong Kong is the media's own irresponsibility. The shift towards sensationalism can be seen in a wider context than the commercial motivation for sleaze. As in other countries of the region where the fear of censorship has been an issue, crime, sex and violence have provided juicy, non-political fare to push up circulation figures, but to avoid political controversy. There is little concrete evidence that Beijing has applied overt pressure to the Hong Kong media since the handover. However, media analysts contend there is a pervasive feeling of self-censorship within an industry which was, for so long, a bastion of western liberal press values in a capitalist Chinese enclave. Although it is too early to judge the longterm trends, the Hong Kong Government has, so far, adopted a hands-off approach. Under these conditions, media watchers tend to agree that the threat to Hong Kong's media at the turn of the century is coming from within the industry itself.

The media plays an important social and political role in Hong Kong. Under the British administration, the media was an effective and powerful watchdog against government failure and abuses of power, and it continues to play this role. This has been particularly important because Hong Kong has not yet established a mature, democratic political system. The history of democracy, despite the political principles of the colonial British administration, is a relatively short story. Universal suffrage was not introduced until 1982, and then only for the election of district boards, the lowest representative level in a three-tiered political structure. It took almost another decade of political agitation by Hong Kong's prodemocracy movement for the then colonial administration to take the next step towards wider democracy. In 1991, 18 seats out of 60 were made available for direct election in the highest political body, the Legislative Council. Of the remaining seats, 21 were reserved for representatives of functional constituencies, or local interest groups, 17 remained for government appointments and 4 for government officials. In 1995, the number of directly elected seats was increased to 20 and is due to be increased to 24 in the year 2000 and 30 in 2004. The Legislative Council is not due to be fully elected under a one person, one vote system until 2007 , and then only under a set of strict requirements including the consent of the Chief Executive.

Under the political framework outlined in the Basic Law (Hong Kong's post-handover constitution) the Legislative Council holds the purse- 
strings, passes the laws and, above all, monitors the daily workings of the Tung Chee-hwa government and its administration. However, mixed electoral arrangements in the Legislative Council mean the majority of members have been drawn from business and political circles, with predominantly conservative political views, and a tendency to support the government. In the first two years as a SAR, the Legislative Council has not been able to operate as an effective check on government. The government is also complaining that with more democracy due to be introduced into the Legislative Council, administrative effectiveness will be hampered, signaling possible difficulties in the functioning of a future genuine democracy.

In this environment the media has served as a more powerful watchdog than the Legislative Council. At the end of 1999, the media exposed a spate of mismanagement in the Urban Services Department, including possible conflict of interest involved in the establishment of a tax consultancy by the wife of a senior tax official, and the mishandling of the chaotic opening of Hong Kong's new airport in mid 1998. Pressure from the media has produced admissions of mistakes from the administration and the appointment of a secretary-level official to deal directly with media inquiries. Reforms in the pipeline include requiring under-performing senior civil servants to quit, and have pegged pay rises to performance. Many senior government officials, groomed in the days of the largely unaccountable colonial British government, are now more willing to talk to journalists, officially or on a background basis. They are also prepared to participate in radio talk-back and provide direct responses to public comments and complaints. In short, the media is functioning as a powerful fourth estate and a welcome part of daily life in the SAR.

Fierce competition within the industry following the East Asian economic downturn has coincided with a decline in professional standards and a growing hostility to the press from some sectors of society, business and government. The media in Hong Kong now stands frequently accused of irresponsible reporting, bad taste, sensationalism, and fabrication. The pressure group, the Society for Truth and Light, set up the 'pollution index' to monitor sex and violence in Hong Kong's newspapers and released the results in April 1999 (Ming Pao, 26 A pril 1999). The three best selling dailies, Oriental Daily News, Apple Daily and The Sun, were identified as the 'most polluted'. While many agree that Hong Kong's media has become 
progressively more politically powerful, the new paradox is that fewer people believe what they read, hear on radio, or see on television. Increasingly the media is being consumed as 'info-tainment', but dismissed as a serious source of information.

A survey of the front pages of the three most popular newspapers in October 1999 found entertainment news dominated, with the Apple Daily reporting on a new paparazzi team being set up by Asia Television, as well as the controversy over the same television station's decision to replace journalists with 'artists' to present the evening news bulletins. The Oriental Daily News devoted one of its entire front pages to a female pornographic actress who allegedly created mayhem in a luxury hotel after taking soft drugs. The Sun honed in on the conviction of a popular singer in a court in Hawaii for stealing a pair of US\$75 sunglasses, which he said he absentmindedly picked up and forgot to pay for.

Media analysts believe it is too early to be certain that the media will continue to operate without political pressure from China. As a June 1999 joint report of the Hong Kong Journalists Association and Article 19: the International Centre Against Censorship, says of Hong Kong

Self-censorship is still a threat to media freedom, but probably no more than we reported in our 1998 publication. We continue to hear reports that certain publications or broadcasters have played down sensitive issues concerning dissident or separatist activities in China...a television station had cut back to just one episode its original plan to broadcast a six-part series on Tibet. However, some observers see the broadcasting on even a single episode, which includes excerpts from an interview with the Dalai Lama, as positive (Hong Kong Journalists' Association and Article 19 1999).

The report also points to the prominent coverage given by the media to the tenth anniversary of the supression of the 1989 pro-democracy movement in China.

Local journalists argue strongly that the Basic Law's infamous Article 23 on subversive activities hangs like an axe over Hong Kong reporters. Article 23 states that the SAR

[S]hall enact laws on its own to prohibit any act of treason, secession, sedition, subversion against the Central Government, or theft of state secrets, to prohibit foreign political organisations or bodies from conducting political activities in the region, and to prohibit political 
organisations or bodies of the region from establishing ties with foreign political organisations or bodies.

Local journalists have remained nervous despite signals that the Tung Chee-hwa government is not rushing to draft new laws to implement Article 23.

\section{Cut-throat diversity}

For just 6.8 million people, Hong Kong produces 26 Chinese-language dailies, eight English dailies, one bi-lingual daily and five dailies in other minority languages-one of the highest levels of media exposure on earth. Most of the dailies also carry Internet editions and Internet access is widespread within the general community. Hong Kong is also served by a government-run radio and television station, two commercial radio stations, and a cable television station. Most households have access to satellite STAR television and people who live near the border can receive mainland Chinese television programs. Except for the three dailies, $\mathrm{Ta}$ Kung Pao, Wen Wei Po and Hong Kong Commercial Daily, which are generally described as pro-Beijing, most print and electronic media are marketoriented and non-ideological. There were a few traditional pro-Taiwan newspapers, such as Hong Kong Times and Hong Kong United Daily, which operated before the handover but they closed down for political and commercial reasons before 1997. The two mass-market newspapers, Oriental Daily News and Apple Daily, have taken up the major share in the Chinese newspaper market, with unofficial figures suggesting they have 70 per cent of market share. Their layout is bold and colourful, offering readers comprehensive low-rent guides to anything from cheap foodstalls to kinky brothels. Oriental Daily News claims a circulation of over 600,000, while Apple Daily says it sells a daily average of 400,000 copies. The Sun, launched in early 1999 as a sister paper of the Oriental Daily News, is believed to rank third with a circulation of less than 200,000. Most of the other dailies sell less than 100,000 daily copies. They include Ming Pao, Sing Tao Jih Pao, Hong Kong Economic Times and Hong Kong Economic Journal, which target educated, middle-income professionals and business executives.

Of the two English-language dailies, South China Morning Post has been the market leader for decades. It sells an average of 110,000 , more than its 
direct rival, The Hong Kong Standard. In addition to providing information to the expatriate and bilingual readers in Hong Kong, the English dailies also form an important channel for information on developments in mainland China to the rest of the world. Hong Kong's newspapers are available on the Internet and provide independent China coverage, from within China, for overseas China-watchers unable to access similar information through the government-controlled Chinese media. Partly because of its location at the southern tip of the mainland and partly because of its tradition of media freedom, Hong Kong has continued to provide a strategic regional base for many international media organisations, including Asiaweek, Financial Times, Far Eastern Economic Review, Cable News Network and International Herald Tribune.

Hong Kong's television viewers have access to 48 domestic and regional channels in various languages. These include four free-to-air commercial channels funded by advertising, 40 pay-TV channels funded by subscriptions, and a variety of free-to-air satellite channels. The two commercial stations, Television Broadcasts Limited (TVB) and Asia Television (ATV) are each licensed to broadcast one Cantonese and one English-language channel until the year 2000. The government announced in late 1998 it would not limit the number of free-to-air licences. Its policy is to gradually open the market to more providers. However, to avoid conflict of interest and a build-up of control by a single media operator, cross-media ownership will continue to apply to domestic free-to-air and pay TV services.

\section{Commercialism versus social responsibility}

Speaking at a lunch with board members of the Newspaper Society of Hong Kong in April 1999, Chief Executive Tung Chee-hwa expressed his concern over developments in the media.

In the past six to 12 months, there have been a lot of views expressed in society. Many people have asked me: Why has the media become more market-oriented? Has it given top priority to making profits and increasing sales? It is true that everybody, every business organisation needs to make money, but apart from press freedom, should the media also shoulder some social responsibility (Hong Kong Standard, 10 April 1999). 
His remarks were similar in tone and content to a speech given by Chief Secretary for Administration, Anson Chan Fang On-sang, in late March 1999. The top SAR leaders are not alone in raising this concern. Various opinion surveys have shown growing public discontent with press commercialism and sensationalism. The first clear signs of declining media ethics were noticed several years ago. In 1996, for example, a weekly magazine ran a cover story claiming a local multi-millionaire was dying of cancer. It was a hoax perpetrated by a 19-year-old high school graduate, for which the magazine was forced to apologize publicly, but the fabricated story merely marked the beginning of the age of fiction and sleaze in the local news media. Other publications reported the fabricated suicides of both pop superstar, Leo Lai, and Yuan $\mathrm{Mu}$, a retired Chinese official who had acted as government spokesman during the 1989 Tiananmen Square crackdown.

Calls for ways to curb media excesses include a controversial proposal to set up a media council to review complaints against the press. Similar to the Press Council in the United Kingdom, the idea drew strong resistance from the industry when it was first mooted in early 1980s. At that time talks on Hong Kong's return to Chinese sovereignty were in their initial stages and the proposal triggered grave fears of curbs on a free press. Now, some influential media figures and officials believe it can be safely pursued. The Hong Kong Journalists' Association has proposed an informal media forum for the industry to tap the views of concerned groups, such as academics. The News Executives Association, whose members are mainly senior journalists and editors, is drafting a set of professional ethics guidelines to promote uniform standards within the industry. The guidelines are due to be completed by the end of 1999 . Although there seems to be a general consensus within the industry that something has to be done to address public concern, there is little agreement on what concrete steps to take.

At a specially convened Legislative Council meeting in April, legislators warned that media organisations had better shape up or risk government intervention. The Democratic Party's Andrew Cheng Karfoo said, 'I don't want to see the Government introducing legislation to govern media conduct and ethics. However, if the trend continues, I'm afraid the authorities would be forced to intervene' (Hong Kong Standard, 
April 21 1999). The whole issue of media credibility, however, goes beyond the question of professional practices on matters such as use of sensational pictures and headlines. It raises a more fundamental question of the role of the media in post-handover Hong Kong, and swings the issue of media content back again into the political arena.

Traditionally, media organisations have aimed to balance the need to maintain commercial viability with varying levels of social responsibility. Despite the existence of some harsh laws on matters such as official secrets, Hong Kong's media has enjoyed minimal interference from the Administration in making independent news judgments and editorial comments. Clearly, the debate over the sleaze element has prompted the Administration to articulate is own stance on the social responsibility of the press. In her speech at a media awards ceremony on $7 \mathrm{March}$, Anson Chan urged the media to ensure the reports and information provided to readers were balanced and objective. '[Press media] should strive to maintain fairness when they try to arouse public discussion, take into account and respect the views and positions of different sides', she said (Fang On-sang 1999).

So as far as government officials are concerned, the media should be obliged to provide fair, balanced and objective information to readers. But whose right or role is it to define the concept of fairness and objectivity? Privately, senior Hong Kong officials have complained that the media has failed to give the public the opportunity to understand government policies and decisions. Officials argue they are not preventing the media from criticising them, but asking for fair coverage. The media, they insist, should not criticise the government for the sake of criticism and should actively support the government when it is on the right track. But critics believe these private views represent pressure on the media in the overall interest of society. This view is closer to former Singaporean Prime Minister Lee Kuan Yew's ideology of press control rather than to the western notion of press freedom.

Because of the sensitivity of the issue of social responsibility, the government has not pushed too openly, or too hard, for controls. Privately, officials are hoping the industry itself will come up with solutions to put their house in order, thus leaving the government out of the potentially explosive censorship debate. 


\section{Threats to freedom of the press}

Setting out a list of 16 benchmarks of Hong Kong's success in his swansong Policy Address in 1996, former Governor Chris Patten highlighted concern over whether the press would remain free after the handover. He asked 'Is the Hong Kong press still free, with uninhibited coverage of China and of issues on which China has strong views? Are foreign journalists and media organisations in Hong Kong still free to operate without controls?'(Patten 1996). Locally and internationally, there were fears about whether self-censorship would become the norm rather than the exception. In a speech in late March 1999, Anson Chan said the first 20 months of the SAR showed great protection of freedom of speech, with journalists continuing to enjoy ample room for independent reporting.

A Government report published to mark the second anniversary of the SAR on 1 July 1999 stated

Hong Kong's media has operated freely and unfettered, generating a robust and critical exchange of views on important matters and government policies or actions. If anything, the media has become more critical and demanding in its role as the 'guardians of public concern' (Hong Kong Government 1999).

At this point it does seem fair to say that the Hong Kong government has silenced cynics within and outside the SAR with its restraint and tolerance towards the local media over the past two years. The Beijing government has also won praise over its hands-off approach in allowing a genuine level of autonomy for the SAR. Top SAR leaders have repeatedly assured local journalists they are not intending to introduce legislative curbs on the media, despite vocal complaints against media abuses. Nevertheless, the high-profile remarks made by Tung Chee-hwa and Anson Chan give a clear signal that the government is not happy with the state of the media.

It is an open secret that Tung Chee-hwa and his top aides feel frustrated and angry with the sharp criticism in some influential newspapers over its handling of the right of abode crisis. These included the leading English daily South China Morning Post, the popular Apple Daily and Hong Kong Economic Journal (a financial daily widely read in business and intellectual circles). They all spoke out strongly against the government decision to seek reinterpretation from the Standing Committee of the Chinese National People's Congress over key provisions in the Basic Law. The 
unprecedented move, later approved by the Standing Committee, has effectively overturned a landmark ruling by the Court of Final Appeal. The government had earlier warned an estimated 1.67 million mainlanders would have the right to reside in the SAR under the final appellate court's ruling on 29 January 1999. After the reinterpretation of the provisions, less than 200,000 will now be given the right. Unconvinced by the government's argument, some parts of the media strongly criticised the reinterpretation as a fatal blow to the rule of law, the independent judiciary and Hong Kong's autonomy. Top officials mounted a vigorous defence and propaganda campaign by writing to newspapers, encouraging their supporters to speak out and send articles to the media.

Recently, former South China Morning Post editor Jonathan Fenby said in a report in the New York Times, '[ $t$ ]here's been a much stronger reaction to the newspaper, from officialdom, from business circles, from members of the establishment, than at any time since the handover' (31 July 1999). Whether these remarks provide any evidence of political pressure remains a matter for debate. It is difficult, however, to rule out the possibility that some journalists do feel the psychological pressure to carefully weigh their words. Some journalists admit they feel the problem of self-censorship does exist, but they have trouble giving concrete examples. The Legislative Council's legal constituency representative Margaret Ng Ngoi-yee, a practicing barrister and a former newspaper publisher, has observed in a New York Times report, 'As a whole, newspapers have become steadily more pro-government since the handover' (31 July 1999). The Tung Cheehwa leadership clearly understands the negative consequences of being seen attempting to gag the media. For Hong Kong, with its economy largely dependent on foreign investment, freedom of the media remains an important benchmark for investors. Businesses would be likely to become jittery over any blatant curbs on the free flow of information and a reduction in accountability of the government, and the Tung Chee-hwa administration is well aware of the potential economic consequences.

\section{Beijing's long shadow}

According to a survey conducted by the University of Hong Kong in April 1999, 41 per cent of respondents felt the media was irresponsible in their reporting. A separate survey done by the Chinese University of Hong 
Kong shows credibility ratings for the media had dropped across the board. About one-quarter of respondents believe there is self-censorship by the media. Conversely, though, 36 per cent said the media had performed better in criticising the government after the handover. But, the same percentage of people, by contrast, found the Hong Kong media had failed to continue criticising and monitoring the mainland Chinese government after the handover. The Chinese University of Hong Kong researchers concluded that local media has become more restrained in criticising China.

China coverage remains the most sensitive aspect of press selfcensorship, reflecting the vast differences between Hong Kong and the mainland over fundamental concepts and values. Not long ago, a mainland-born Hong Kong reporter $X_{i}$ Yang was jailed for what would usually be considered scooping his colleagues by revealing plans to sell gold and raise interest rates. $\mathrm{X}$, who worked for the Ming Pao daily, was convicted of espionage charges in a Chinese court. He was sentenced to a 12-year jail term in March 1994 and freed on probation in early 1997 before the handover. He has now emigrated. Xi Yang's case had a far reaching impact. Some China-beat Hong Kong journalists have since resigned, fearing they could become the next victims. Others have clearly become more cautious in dealing with sensitive mainland issues. Both journalists and members of the public hold a strong view that self-censorship in relation to China has become a problem. The problem is that Hong Kong and the mainland have different political systems and different concepts of freedom of the press.

One contentious example is the ongoing issue of the status of Taiwan. Mainland China has consistently claimed sovereignty over Taiwan, despite the reality of the anti-communist administration in Taipei. So sensitive is the Taiwan issue for Beijing, that nations with diplomatic ties to mainland China must relegate Taiwan's representatives to vaguely named commercial or tourist offices. Earlier this year, Taiwan's President Lee Teng-hui defined cross-Straits tensions as a problem between 'two separate states', launching a campaign which infuriated Beijing. When the government-run Radio Television Hong Kong (RTHK) broadcast remarks by Taiwan's unofficial representative in the SAR elaborating on the controversial concept, pro-China newspapers in Hong Kong were quick to lambast RTHK editorial staff for 'going far beyond the boundary of 
'press freedom' and 'independent editorial line'. The RTHK was accused of violating the 'one country, two systems' principle by which China governs Hong Kong and challenging the Basic Law by propagating divisive advocacy. In RTHK's defence, the Assistant Director of Broadcasting (Radio) Peter Shiu Lo-sin wrote in the South China Morning Post,

[o]ne wider issue is the difference between 'promoting/advocating' and 'reporting/discussing.' Article 23 of the Basic Law guarantees freedom of speech and of the press. It is the firm view of our editorial colleagues and I am sure that of most journalists in Hong Kong, that discussing and debating an issue in the media does not in any way constitute an act of advocacy (9 August 1999).

The sharp attacks on RTHK by the pro-China media sent shivers down the spines of Hong Kong journalists because of the potential threat to press freedom and the broader question of freedom of expression under Article 23 in the Basic Law. The government may have indicated there is no urgency in enacting the new legislation, but it has never ruled out its future use. The ferocity of the criticism of RTHK indicated strong pressure from some quarters of the community for the media to adopt the Chinese mainland position when dealing with sovereignty issues. Any future legislation on Article 23 could impact on the media's coverage of issues relating to sovereignty and Communist rule. Will the Hong Kong media be allowed to give their backing to the 'two states theory'? Will journalists be allowed to report on the issue, discuss and analyse it, or raise it for a public debate? Will the SAR be given an entirely free hand to legislate on Article 23?

Article 23 was written into the Basic Law at the latter stage of the fiveyear-long drafting process. It responded to the historic opposition en masse by Hong Kong people against China's crackdown on Tiananmen demonstrators on 4 June 1989. Shocked by scenes of more than 1.5 million people, representing one out of every four Hong Kongers, marching in streets to condemn the shootings, Beijing was adamant that an antisubversive provision in the Basic Law would uphold the authority of the ruling communist regime. The vociferous attacks against President Lee over his 'two states theory' and the crackdown in the northern summer of 1999 against followers of the Falun Gong, a religious sect in mainland China, reflect the depth of anxiety among Beijing leadership over threats 
to its rule. It is hard to imagine the SAR government will not quietly consult Beijing when it begins drafting the anti-subversive legislation.

More than a year before the handover, mainland Chinese officials had already spelled out their views on Article 23. In June 1996, the then head of the Chinese State Council's Hong Kong and Macau Affairs Office, Lu Ping, said the Hong Kong press would not be allowed to advocate two Chinas after 1997 (South China Morning Post, 3 June 1999). Nor was the SAR given the power to advocate independence for Hong Kong and Taiwan under the 'one country, two systems' formula. Journalists are puzzled and worried that it will be up to the authorities to determine arbitrarily what is objective reporting and what is advocacy. The attacks from pro-China media against the RTHK do not augur well for the preservation of unfettered freedom for the media when Article 23 is put on the agenda of legislative program.

\section{Who will defend the media?}

The China factor aside, the future of freedom of the press and speech rests with the resolve of SAR leaders and the community at large to uphold it. Before the handover there was no shortage of comforting promises. In January 1997, Anson Chan urged all Hong Kong journalists to

practise their profession after 1997 as they have practised it, continue to write the stories and editorials that deserve to be written, responsibly, objectively without fear or favour...How well they do their job after the transition will to a very large extent decide how well our other freedoms will be protected (Fang On-sang 1997).

Behind the upbeat note from Anson Chan was the idea that the main threat would come from China, after the handover. Instead, the direct threat from China failed to materialise and the Hong Kong press began to pose a more imminent threat to the authority of the SAR, prompting new local pressures on journalists. Against this background, it is interesting to note the shift in emphasis by Tung Chee-hwa and Anson Chan on the need for the media to fulfill its social responsibility and behave themselves. Conspiracy theorists believe it may be a curtain raiser to some form of future controls over the media.

A tighter grip on the media would be likely to receive the blessing of the central government in Beijing. Speaking to a group of senior journalists 
in mid-July, a deputy director of the Hong Kong and Macau Affairs Office Liu Minqi said that news media 'should explain government policies' and 'reflect public opinion to the government' (South China Morning Post, 20 July 1999). His remarks are in line with the calls by SAR leaders for officials to fulfil their social responsibility while exercising their freedoms.

Like other freedoms and rights, the concept of a free press is entrenched in Hong Kong values. Anyone in the street will speak highly of the importance of a free press which works without fear and favour. But when asked by pollsters from the Baptist University of Hong Kong what is the most important area for more government effort, protecting freedom of the press ranks fourteenth. It follows areas such as luring more tourists, reducing pollution, improving people's livelihood and ensuring economic growth (Hong Kong Transition Project 1999). Positively speaking, it could be seen as a vote of 'everything is fine' with press freedom. Yet it might also reflect the prevalent feeling in the community that the problem with the news media now is not a question of whether or not they are free. Rather it is a question of whether they are excessively free to publish unwarranted criticism of officials, to indulge in trials by media and gross distortions of truth, all of which, in themselves, pose a threat to other freedoms in society. Some media analysts fear the public might become so frustrated and fed up that they are ready to accept some kind of press controls. If the credibility of the media continues to decline, there is a stronger likelihood of public support for curbs on the media.

In his annual Policy Address delivered on 6 October 1999, Chief Executive Tung Chee-hwa warned that press freedom should not become a pretext for disregarding media ethics. He said, 'it is inexcusable for any media operator to resort to pornography, violence, libel or misrepresentation simply for profit'. Professional ethics and social responsibilities of the media, Tung Chee-hwa pointed out, 'is an issue of prime public concern which deserves the Government's due attention...The SAR Government awaits with interest the outcome of the public consultation exercise' (Chee-hwa 1999).

Tung Chee-hwa was referring to a set of controversial proposals published by the quasi-official Law Reform Commission in August 1999 for a four-month consultation concluding at the end of November. The key proposal is the establishment of a statutory Press Council appointed 
by the Chief Executive to handle complaints and initiate investigations over privacy intrusions by the media. The Press Council would be empowered to impose a maximum fine of $\mathrm{HK} \$ 500,000$ on a newspaper for a first offence in a serious breach of a privacy code. For a second or subsequent offence a publication would face a maximum fine of $\mathrm{HK} \$ 1$ million.

The proposal has already been met with strong opposition from all journalists' groups, newspapers and many academics. They are worried the new body could mark the beginning of curbs on press freedom. However, opinion polls reflect a mixed response from the public. One major finding was that the public generally considered the media to have acted irresponsibly and to have intruded into the privacy of individuals. The government has said it remains open minded about the proposal, despite a strong hint from Tung Chee-hwa that his administration will have to do something if the media fails to introduce some kind of selfregulating measures.

The Independent Law Reform Commission, which is chaired by a university professor and plays an instrumental role in legislation, will make its final proposal to the government after taking into account the range of views collected during the consultation. The ball is then in Tung Chee-hwa's court for a final decision on the long-standing issue of media excess.

Two years after the change of sovereignty, life in Hong Kong remains much the same as it was under British rule. Following months of consecutive negative economic growth, in mid 1999 signs emerged that the worst is over. Politically, there have been no mass arrests of dissidents. Demonstrations remain part of the daily life. The annual 4 June candlelight vigil in Victoria Park, marking the anniversary of the Tiananmen Square massacre, attracted a higher-than-expected turnout $-70,000$ according to the organisers. Many media organisations gave prominent coverage to the memorial activities, now seen as a symbol of the preservation of Hong Kong's civil liberties and free lifestyles under Chinese rule.

In her speech in March, Anson Chan said there are new problems to be explored and solved as the policy of 'one country, two systems' is implemented. The media can play a much bigger role in the historical 
process. Apart from monitoring the operations of the government and reflecting public opinion, the media play an important role in shaping community thinking and raising civic awareness. Media proprietors, executives and journalists, however, have yet to show a broad consensus on the need to define their role and the boundaries of press freedom in the new political game. The challenge is for them to give full play to the fourth estate to contribute to the development of a stable, equitable, free, democratic and compassionate society under the formula of 'one country, two systems'. 